Abstracta Iranicanica

Revue bibliographique pour le domaine irano-aryen

Volume 28 | 2007

Comptes rendus des publications de 2005

\title{
"Silk Road to Success ». The National Interest, décembre 2004-janvier 2005, pp. 65-72.
}

\section{Anicée Van Engeland}

\section{(2) OpenEdition}

1 Journals

\section{Édition électronique}

URL : http://journals.openedition.org/abstractairanica/20111

DOI : 10.4000/abstractairanica. 20111

ISSN : 1961-960X

Éditeur :

CNRS (UMR 7528 Mondes iraniens et indiens), Éditions de l'IFRI

\section{Édition imprimée}

Date de publication : 15 mai 2007

ISSN : 0240-8910

\section{Référence électronique}

Anicée Van Engeland, « «Silk Road to Success ». The National Interest, décembre 2004-janvier 2005, pp. 65-72. », Abstracta Iranica [En ligne], Volume 28 | 2007, document 478, mis en ligne le 18 septembre 2007, consulté le 25 septembre 2020. URL : http://journals.openedition.org/abstractairanica/20111 ; DOI : https://doi.org/10.4000/abstractairanica.20111

Ce document a été généré automatiquement le 25 septembre 2020.

Tous droits réservés 


\section{«Silk Road to Success ». The National Interest, décembre 2004-janvier 2005, pp. 65-72.}

\section{Anicée Van Engeland}

1 L'A. souligne la mobilisation importante des électeurs afghans en dépit des intimidations et dangers et le bon déroulement des élections d'octobre 2004 qui ont surpris beaucoup d'acteurs politiques mondiaux. Qualifiant d'inévitable la corruption existante l'A. estime que la large participation de la population afghane à ce vote démontre que la démocratisation du pays est en marche et que les critiques des ÉtatsUnis annonçant l'échec de ces élections ont eu tort.

INDEX

Thèmes : 13.2. Afghanistan

\section{AUTEURS}

ANICÉE VAN ENGELAND

Paris 